\title{
A Fantasy of Justice
}

Un fantasme de justice

John O'Brien

\section{(2) OpenEdition \\ Journals}

Electronic version

URL: http://journals.openedition.org/shakespeare/723

DOI: 10.4000/shakespeare.723

ISSN: 2271-6424

Publisher

Société Française Shakespeare

\section{Printed version}

Date of publication: 1 November 2004

Number of pages: $245-258$

ISBN: 2-9521475-0-7

\section{Electronic reference}

John O'Brien, "A Fantasy of Justice », Actes des congrès de la Société française Shakespeare [Online]

21 | 2004, Online since 01 January 2007, connection on 03 May 2019. URL : http://

journals.openedition.org/shakespeare/723; DOI : 10.4000/shakespeare.723 


\section{Shakespeare et Montaigne vers un nouvel humanisme}

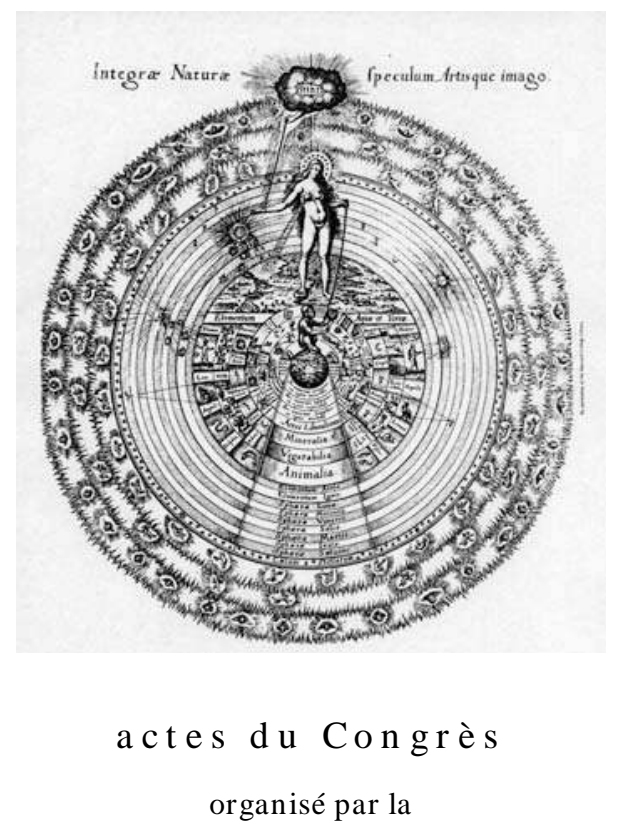

SOCIÉTÉ FR ANÇAISE SH AKESPEARE en collaboration avec la

S OC I É T É I N T E R N A T I O N A L E DES AM I D E M O N A I G N les 13,14 et 15 mars 2003

$$
\begin{gathered}
\text { textes réunis par } \\
\text { Pierre KAPITANIAK } \\
\text { sous la direction de } \\
\text { Jean-Marie MAGUIN }
\end{gathered}
$$




\section{COMITÉ SCIENTIFIQUE :}

Margaret Jones-Davis

Gisèle Venet

Jean-Marie Maguin

Yves Peyré

François Laroque

Pierre Kapitaniak

\section{COUVERTURE :}

Robert Fludd

Utriusque Cosmi Historia (1617-19)

planche 17

conception graphique et logo

Pierre Kapitaniak

\section{(C) 2003 Société Française Shakespeare}

Institut du Monde Anglophone

Université de Paris III - Sorbonne Nouvelle

http:// univ-montp3.fr/SFS/

5 rue de l'École de Médecine

75006 Paris

Diffusion :

AVL DIFFUSION

Parc Euromédecine

34198 MONTPELLIER CEDEX 5

ISBN 2-9521475-0-7

Tous droits de traduction, de reproduction et d'adaptation réservés pour tous les pays 
A Fantasy of Justice

\title{
John O'BRIEN
}

\begin{abstract}
Montaigne's essay «Des cannibales " contains the well-known passage that Shakespeare incorporated into The Tempest via Florio's translation of The Essays. The present paper will examine the relationship of this passage, in each of the two writers, to the notion of princely justice with which essay I, xxxi ends and with which the play almost ends. In both cases, questions of princely justice are framed in a setting that is geographically and ideologically distanced. Both writers ask, explicitly and implicitly, what kinds of justice are possible, whether justice is only possible in such settings, and whether justice is itself just a fantasy, given the injustice which Montaigne describes in his essay. Part of the discussion will examine the views of modern-day critics, especially David Quint, Montaigne and the Quality of Mercy and Michel de Certeau.

Un fantasme de justice L'essai "Des Cannibales" contient le passage bien connu que Shakespeare incorpora à La Tempête à partir de la traduction de Florio. II s'agira ici d'examiner le lien entre ce passage chez chacun des deux écrivains et la notion de justice du prince posée à la fin de l'essai xxxi du livre I et qui clôt presque la pièce. Dans les deux cas, la question est posée dans un contexte géographique et idéologique permettant une distanciation. Les deux écrivains s'interrogent, explicitement et implicitement, sur les formes possibles de la justice, et se demandent si la justice est seulement possible dans les contextes envisagés et $s i$ la justice elle-même est un fantasme, au vu de l'injustice dont Montaigne dessine les traits dans son essai. Pour partie, nous examinerons le point de vue des critiques actuels, notamment ceux de David Quint dans "Montaigne et la nature de la miséricorde " et de Michel de Certeau.
\end{abstract}

I n 1550-51, two men engaged in a dispute. The dispute took place in Valladolid and its subject was the native people of the Americas. For one of the disputants, the native peoples were barely human; they were lascivious and idolatrous, and indulged in unnatural practices such as cannibalism and human sacrifice. There was consequently no imperative for the Spanish settlers or the Spanish authorities in general to accord the natives the usual rights that were normal between human beings; for the native peoples were not human; they were little better than animals. The second disputant vigorously opposed this view. He argued that the native peoples had rational souls like the settlers that colonised their land and that consequently they were every bit as human as the colonisers and must be treated as their ethical equals. The Spaniards had, indeed, a moral obligation towards the natives and must discharge this obligation before they incurred the wrath of God.

The two disputants were Sepúlveda and Las Casas respectively. Anthony Pagden, who has carried out extensive recent research into the context and background of this dispute, and the personalities 
involved in it, fills in much of the detail. ${ }^{350}$ The two men probably never actually met, he claims, and their dispute was held over a prolonged period with statements and counter-statements from each side adjudicated by a panel of judges. Las Casas spoke for five days, refuting passionately not only all that Sepúlveda had written, but also everything that had ever been written against the native Americans. Sepúlveda replied with twelve objections; Las Casas countered with twelve refutations. It was only when the president of the panel, Soto, intervened that the debate drew to an inconclusive close.

Despite the lack of formal pronouncement in his favour, Las Casas emerged as the moral victor. His brief account of the destruction of the Indies became a bestseller and he included in it a record of his debate with Sepúlveda. A French translation of this work was made by Jacques de Miggrode and published in Antwerp in 1579 at the behest of the Dutch States General who commissioned the work as a warning against Spanish imperialism. ${ }^{351}$ Las Casas's work, and his committed defence of the native inhabitants of the Americas, raised persistent and thorny problems, of justice particularly: should natives be treated equitably, and if so, how? What rights could they be said to have? And a related issue, not directly raised or contested by Las Casas: in what sense, if any, could European monarchs claim jurisdiction over the New World? What was the basis of their authority apart from the brute exercise of power?

The resonances of this heated debate reverberate elsewhere in the literature of the period that touches on the question of the New World. The Tempest is no exception to this rule. In particular, the close of the play throws up issues of special interest that claim our attention,

\footnotetext{
350 Anthony Pagden, Peoples and Empires: Europeans and the Rest of the World, from Antiquity to the Present, London, Phoenix Press, 2001, p. 77-79, to which my discussion here is indebted. The first chapter of Pagden's earlier work, Spanish Imperialism and the Political Imagination, New Haven and London, Yale University Press, 1990, "Dispossessing the Barbarian: Rights and Property in Spanish America”, p. 13-36 (p. 32-33 for Las Casas), elucidates the larger context of Las Casas's work, detailing the debates that raged over this issue of sovereignty, natural rights and the nature of the New World inhabitants in the years before and after the contest between Las Casas and Sepúlveda. Pagden's European Encounters with the New World, from Renaissance to Romanticism, New Haven and London, Yale University Press, 1993, chapter 2, "The Autoptic Imagination", p. 51-87, gives extensive coverage to Las Casas as an instance of the eyewitness account.

${ }^{351}$ Tyrannie et cruautez des Espagnols perpetrees es Indes Occidentales, qu'on dit Le Nouueau monde, Brieuement descrites en langue Castellane, par l'Evesque Don Frere BARTHELEMY DE LAS CASAS ..., fidelement traduictes par IAQUES de MIGGRODE, Antwerp, Ravelenghien, 1579.
} 
notably in relation to questions of distributive and commutative justice. ${ }^{352}$ The mood is one of reconciliation and Prospero is prompted to it by Ariel:

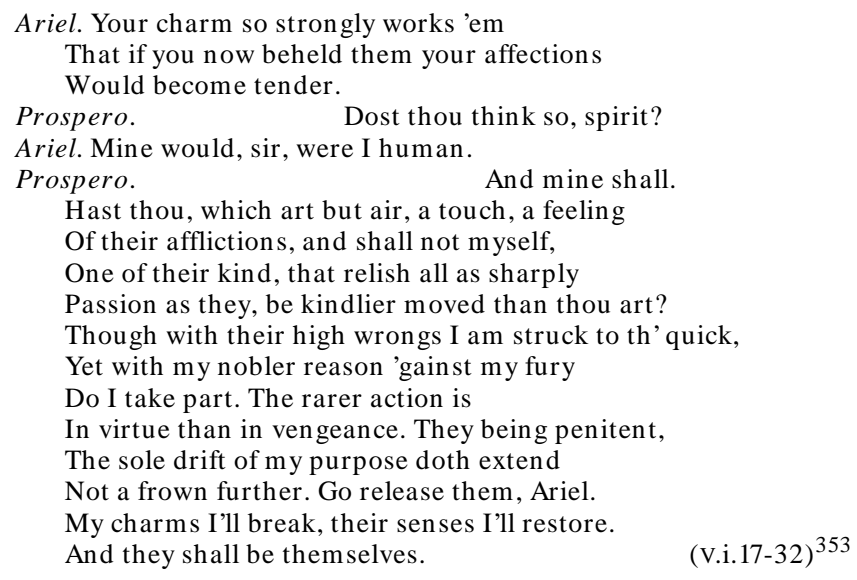

Prospero's decision is an object lesson in the clemency the Prince was expected to display: the justice by which vengeance could justifiably be exacted is foregone in favour of leniency, commuted into mercy in view of the courtiers' penitence. Prospero will abjure "this rough magic", his "so potent art" (v.i.50). It is a sign that the end of the play approaches and with it the resolution of the drama. Yet resolution will not be reached, forgiveness not bestowed, without a reminder of the wrongs committed. To Alonso, Prospero says: "Most cruelly/Didst thou, Alonso, use me and my daughter./ Thy brother was a furtherer in the act. - / Thou art pinched for 't now, Sebastian" (v.i.71-74), while his words to Antonio highlight the tensions that led to the raising of the tempest in the first place:

\footnotetext{
352 For the definition of justice in the Renaissance and its background in classical and humanist thought, see Ullrich Langer, Vertu du discours, discours de la vertu: Littérature et philosophie morale au XVI siècle en France, Geneva, Droz, 1999, p. 123-29, and p. 12729 for the division of particular justice into distributive and commutative and their distinction.

353 All references incorporated in the text are to The Norton Shakespeare, ed. Stephen Greenblatt, Walter Cohen, Jean E. Howard and Katharine Eisamen Maus, New York and London, Norton, 1997. Quotation is by act, scene and line(s).
} 
Flesh and blood,

You, brother mine, that entertained ambition,

Expelled remorse and nature, whom, with Sebastian -

Whose in ward pinches therefore are most strong -

Would have killed your king, I do forgive thee,

Unnatural though thou art.

Alonso echoes these ideas:

\section{Thy pulse}

Beats as of flesh and blood; [...

Thy dukedom I resign, and do entreat

Thou pardon me my wrongs.

Prospero then addresses Antonio:

For you, most wicked sir, whom to call brother

Would even infect my mouth, I do forgive

Thy rankest fault, all of them, and require

My dukedom of thee, which perforce I know

Thou must restore.

(V.i.132-36)

After the distributive justice comes the commutative: Prospero, a little later, goes on to say to Alonso:

My dukedom since you have given me again,

I will requite you with as good a thing.

(V.i.170-71)

And shortly afterwards we learn through Gonzalo what this commutation is to be:

Was Milan thrust from Milan, that his issue

Should become kings of Naples?

$$
\text { ...in one voyage }
$$

Did Claribel her husband find in Tunis,

And Ferdinand her brother found a wife

Where he himself was lost; Prospero his dukedom

In a poor isle; and all of us ourselves,

When no man was his own.

(V.i.208-10, 211-16)

The restoration of order depends on equity, the symmetrical alignment of distributive and commutative justice; and we might note that Gonzalo's speech just quoted contains both. The restoration depends further on the recognition and acceptance of political and social place, as well as being once more in one's right mind (one's psychological place); each element reasserts in the process the power and authority 
of the magus and provides definitive proof of his ability to bring his magic to successful fruition.

There is, we know, a notable exception to this rule of perfect adequation in the economy of justice. That exception - deferred until after the scene of formal reconciliation, but before Prospero's address to the audience - is Caliban. To all intents and purposes, a similar discursive pattern is followed: Caliban's conspiracy had been discovered by Ariel and Prospero underscores the crime:

These three ${ }^{354}$ have robbed me, and this demi-devil,

For he's a bastard one, had plotted with them

To take my life.

(V.i.275-77)

Despite the gravity of the crime - a crime even more serious than that of Prospero's brother, Antonio - Caliban and his fellow conspirators are offered clemency. Prospero addresses Caliban:

Go, sirrah, to my cell.

Take with you your companions. As you look

To have my pardon, trim it handsomely.

And Caliban's reply is seeming acquiescence, an indication that he has come to his senses and returned to his proper social place of subservience:

Ay, that I will; and I'll be wise hereafter,

And seek for grace.

Distributive justice, then, in the case of Caliban. But where is the commutative justice? It might be argued that in declining to exact vengeance on Caliban, Prospero effectively renounces commutative justice - since vengeance, "an eye for an eye", was an acknowledged form of commutative justice. ${ }^{355}$ Yet the issue goes deeper. If Caliban has been a conspirator against Prospero's life, it is because Prospero has been a usurper of Caliban's isle: as the creature says at the beginning of the play, "this island's mine, by Sycorax my mother,/which thou tak'st from me" (I.ii.334-35). Greenblatt draws the appropriate inference: "..across the vast gulf that divides the triumphant prince and the defeated savage, there is a momentary,

354 Meaning Caliban, Stefano and Trinculo.

355 Cf. Langer, Vertu du discours, p. 128-29. 
enigmatic glimpse of a hidden bond: 'this thing of darkness', Prospero says of Caliban, 'I/ Acknowledge mine' (v.i.278-9). The words need only be a claim of ownership, but they seem to hint at a deeper, more disturbing link between father and monster, legitimate ruler and savage, judge and criminal". ${ }^{356}$

Even before Greenblatt had written those words, critics had not been slow to understand the implications of this situation for colonialism and colonialist discourse. The seminal articles by Francis Barker and Peter Hulme, and by Paul Brown, have offered penetrating assessments of The Tempest in terms which illuminate its relationship to modern day colonialist and political theory as well as to Elizabethan and Jacobean conceptualisations of the same. ${ }^{357}$ The postcolonialist line that these articles adopt has, however, met with strong challenge in recent years. Deborah Willis specifically takes issue with Brown's article in particular, arguing that the play "is more significantly engaged in arousing desire for, and displaying the power of, a ruler at the core who can contain a tendency toward oligarchy and division" 358 , and that it is Antonio who represents the real threat since his "evil is conceived as an innate quality" and "cannot be banished decisively by retributive justice". ${ }^{359}$ Other critics offset the postcolonialist argument by an emphasis on "the play's engagement with its own historical moment" and thus the dimension of early seventeenth-century European politics they see the play as embodying. ${ }^{360}$ It is with this debate in mind that we can situate The Tempest in respect of its dispensation of justice. Prospero stands right with Sepúlveda in believing implicitly that native peoples have no claims of legitimacy to their own lands compared with the more substantive claim of

356 The Norton Shakespeare, p. 3053

${ }^{357}$ Francis Barker and Peter Hulme, "Nymphs and Reapers Heavily Vanish: The Discursive Con-Texts of The Tempest", in Alternative Shakepeares, ed. John Drakakis, "New Accents", London and New York, Methuen, 1985, p. 191-205; Paul Brown, "This Thing of Darkness I Acknowledge Mine': The Tempest and the Discourse of Colonialism" in Political Shakespeare: New Essays in Cultural Materialism, ed. Jonathan Dollimore and Alan Sinfield, Ithaca, Cornell University Press, 1985, p. 48-71.

358 Deborah Willis, "Shakespeare's Tempest and the Discourse of Colonialism" in William Shakespeare: The Tempest', A Case Study in Critical Controversy, ed. Gerald Graff and James Phelan, Boston and New York, Bedford/St Martin's, 2000, p. 256-68; p. 261. Willis's article originally appeared in Studies in English Literature 1500-1900 29/2 (1989).

359 Willis, "Shakespeare's Tempest", p. 264.

360 So David Scott Kastan, "The Duke of Milan/And his Brave Son': Old Histories and New in The Tempest", in Graff and Phelan, p. 269-86; p. 275. 
European monarchy backed by the exercise of God-given power. By contrast, it is Caliban himself who articulates his own right to the island, not through canon law as Las Casas was to attempt to do on the natives' behalf, but through inheritance from his mother; against the distributive justice by which Prospero gives the island to himself, Caliban sets natural justice which he sees Prospero as flouting. And as Meredith Anne Skura justifiably points out, the play allows Caliban the extensive airing of his views and of the injustices he suffers:

Shakespeare was the first to show one of $u$ s mistreating a native, the first to represent a native from the inside, the first to allow a native to complain on stage, and the first to make that New World encounter problematic enough to generate the current attention to the play. ${ }^{361}$

It can be argued, of course, that some sort of justice, of a rough and ready kind, is enacted in respect of Caliban, inasmuch as Prospero "magnanimously" forbears to punish him for his conspiracy and Caliban presumably does get the island back when all have departed. However, this latter development is an involuntary concomitant of the teleology of justice (and of the drama), not an essential component of it; and he consequently receives nothing in exchange for the wrongs he has suffered because it is not admitted that he has suffered any wrongs. The conclusion of the drama leaves this particular ethical issue inconclusive.

The problem is compounded by a further dimension which Greenblatt describes as "two different accounts of the nature of mimetic economy", constituting "a model of unresolved and unresolvable doubleness":

the island in The Tempest seems to be an image of the place of pure fantasy, set apart from surrounding discourses; and it seems to be an image of the place of power, the place in which all individual discourses are organized by the half-invisible ruler. [...]. The aesthetic space [...] is constituted by the simultaneous appropriation of and swerving from the discourse of power. ${ }^{362}$

That doubleness is likewise written into the justice that power dispenses. On the one hand, justice can be enacted in such a way as to

\footnotetext{
${ }^{361}$ Meredith Anne Skura, "Discourse and the Individual: The Case of Colonialism in The Tempest", Shakespeare Quarterly 40 (1989), p. 42-69; p. 60.

362 Stephen Greenblatt, Shakespearean Negotiations: The Circulation of Social Energy in Renaissance England, Oxford, Clarendon Press, 2001, p. 158-59.
} 
bring about reconciliation between opposing political interests and the preservation of dynastic order before power itself is voluntarily laid down by Prospero. On the other hand, justice is enacted by exclusion from the commutative system of a creature who has rights under natural law and whose lèse-majesté is forgiven only on condition that he accepts subservience in a hierarchy that is alien to him. These doublenesses, as Greenblatt also sees, derive from, or at the very least are intimately connected to, the status of art, in particular the status of Prospero's art in The Tempest. The manifestations of the magus's power are manifestations of high art: the ability to conjure the storm in the first place, the activity of Ariel who symbolises Prospero's "word in action, the precise, fluent fulfilment of his desires", 363 the deft dovetailing of Prospero's plotting of events and circumstances with the larger structural dynamic of the play itself - all these bear witness to the magician's artifice and the effortless ease with which he organises the mise en scène of incident and character in a play that is selfconsciously, self-advertisingly proud of its alluring fictionality. By the same token, justice can be indexed as a positive product of this imaginative world which invests fantasy with a value as a philosophical and indeed in this case political ideal, able to bring about the harmonisations on which the play's dénouement depends. At the same time, however, what Prospero restores is an order of culture, owing to the supernatural control he wields. The fantasy of justice he creates is itself not a natural product, but an ideological one, premised on the assumption that art and nature can coincide. The self-reflexive nature of the play highlights just how precarious that ideological construct is: it is a dream that rounds off a sleep, an insubstantial pageant on a shadow stage.

Let me summarise the argument to this point. The fantasy of justice in The Tempest is a political and social aspiration, best enacted - because most visibly, most potently enacted - in a place set apart from any one particular social order and yet subtending them all; the fantasy of justice is just that - a fantasy, a delusion, only to be enacted in a place set apart because pragmatically incompatible with any actually-instantiated political or social order: between these two poles

363 Terry Eagleton, William Shakespeare, "Re-Reading Literature", Oxford, Blackwell, 1986, p. 94. 
lies the complex dialectic that Shakespeare's play figures forth as a problem allowing of no simple solution.

It is not, of course, the only point at which tensions and disturbances come to the surface in this play. Gonzalo's speech on the commonwealth in Act 2 provides an obvious instance:

I' th' commonwealth I would by contraries

Execute all things. For no kind of traffic

Would I admit, no name of magistrate;

Letters should not be known; riches, poverty,

And use of service, none; contract, succession,

Bourn, bound of land, tilth, vineyard, none;

No occupation, all men idle; all;

And women too - but innocent and pure;

No sovereignty -

And he continues shortly afterwards:

All things in common nature should produce

Without sweat or endeavour. Treason, felony,

Sword, pike, knife, gun, or need of any en gine,

Would I not have; but nature should bring forth

Of its own kind all foison, all abundance,

To feed my innocent people.

(II.i.159-64)

It is a purposely oppositional speech, and at a number of different levels. It is, for one thing, not a description that should be regarded as co-extensive with the island that the shipwrecked courtiers find on their arrival. The island on which they land seems "to be desert" (II.i.35) - both infertile and uninhabited - whereas Gonzalo calls for a place where "nature should bring forth/Of it own kind all foison, all abundance". Within the space that is demarcated by the staging of the drama, a further conceptual space is thus opened up by Gonzalo's musings. If Prospero's island is at a remove from any contemporary reality or setting, then Gonzalo's commonwealth is at a greater remove still. Indeed, Gonzalo's description of it expressly seeks "T'excel the Golden Age" (II.i.168); it is avowedly Utopian, as Frank Lestringant has shown in this conference. ${ }^{364}$ And yet it does, despite that, pass comment on issues that prove central to the play. One might note, for example, the way sovereignty is discussed in the very presence of Alonso and Antonio, a prefigurement of the challenge that Caliban

364 “Gonzalo's Books", and his Le Cannibale. Grandeur et décadence, Paris, Perrin, 1994, p. 163-69. 
constantly presents to the legitimacy of Prospero's power. More insistent is Gonzalo's emphatic dismissal of the legal system - "no name of magistrate" - and with it the legislation that covers contract and succession: justice will not be maintained by distribution and commutation operating under the general name of equity, but regulated by Nature, if regulated at all. This is in striking contrast to the very dispensation that Prospero himself will enact, and a salutary reminder that this dispensation is itself the apogee of a finely tuned art that fantasises a solution to the dramatic and political dilemmas, a solution that it assumes is acceptable to Nature or is indeed indistinguishable from it.

Gonzalo's speech does not mention cannibals or Calibans; Montaigne's essay, from one page of which the speech is adapted, names the cannibals directly, in its title, and indirectly, through the use of the term "sauvage", which enables the essayist to deploy paradoxes and equivocations about who the "sauvages" really are - they who cleave to the state of Nature, or we who have corrupted and abandoned it. The paradoxical eulogy that Montaigne sketches near the beginning of his essay shares with Gonzalo's encomium an oppositional stance: in the immediate context, it is intended as part of an imaginary debate between the essayist and Plato whose conception of the ideal state is, for Montaigne, bettered by native society, not least because the description of Brazilian life is based on experience. It seeks, therefore, not to open up an "ailleurs" that is remoter even than Prospero's island, but rather to import the findings of explorers and adventurers into the ambit of Western society and in so doing to dismantle the claims of that society to cultural superiority. In particular, of course, Montaigne uses the polyvalence of the term "barbarie" in order to highlight the barbarity of the French Wars of Religion - the real cannibals are already in France, not outside it. The parallelism in the terminology at this point underscores the use of Brazilian culture as a form of critique, for the earlier sentence "Les paroles mesmes qui signifient le mensonge, la trahison, la dissimulation, l'avarice, l'envie, la detraction, le pardon, inouies" 365 is partly repeated and echoed in the sentence that acts as a commentary on the cannibalism and cruelty of the Civil Wars: “...il ne se trouve jamais aucune opinion si desreglée

365 Les Essais de Michel de Montaigne, édités par Pierre Villey, réédités par V.-L. Saulnier, Paris, Presses Universitaires de France, 1965, p. 206-207. 
qui excusat la trahison, la desloyauté, la tyrannie, la cruauté, qui sont nos fautes ordinaires" (I, 31, 210).

To these well-known strategic features of Montaigne's use of the cannibals can be added a third aspect in which the essayist's aim is, to quote André Tournon, to "précise[r] le partage entre le probable réalité lointaine, perçue à travers des témoignages - et le contrôlable le sens de ces témoignages, et notre propre attitude envers les renseignements qu'ils fournissent". ${ }^{366}$ It is this dimension of Montaigne's essay that requires further comment. It may at first sight seem strange to evaluate what he says about the cannibals in terms of justice (the terms Montaigne explicitly proposes are those of valour), especially in "the culture that cannot pardon", to quote David Quint's description of cannibal society. ${ }^{367}$ Nonetheless, elements of cannibalistic customs recall forms of distribution and commutation, but arranged in such a way as to block their easy assessment in standard Western terms. Thus in respect of property and inheritance, Montaigne notes as follows:

[Les vieillards] laissent à leurs heritiers en commun cette pleine possession de biens par indivis, sans autre titre que celuy tout pur que nature donne à ses creatures, les produisant au monde. (I, 31, 210)

A recognisable system of inheritance is in voked, only to be qualified by the remainder of the sentence. Moreover, the cannibals all call each other "freres", erasing or at the very least blurring as a consequence distinctions of birth and breeding. A more complex example occurs in the case of vengeance which, Montaigne reports, is the object of cannibalistic practice. We know from The Tempest that the regulation of vengeance fell squarely into the domain of justice. Yet at just this point Montaigne allows the full otherness of cannibal culture to emerge from his account. As Michel de Certeau has pointed out, the actual aim of cannibal vengeance is to force the captive into an admission of weakness; there is, says de Certeau, an economy of speech in which the body is the price. ${ }^{368}$ The ritual of cannibalism prescribes a practice that

366 André Tournon, Montaigne: La glose et l'essai, édition revue et corrigée, précédée d'un Réexamen, Paris, Champion, 2000, p. 220-21.

367 David Quint, Montaigne and the Quality of Mercy: Ethical and Political Themes in the Essais', Princeton, Princeton University Press, 1998, chapter 3, "The Culture That Cannot Pardon: 'Des cannibales' in the Larger Essais", p. 75-101.

368 Michel de Certeau, "Montaigne's 'Of Cannibals': The Savage 'I"' in Heterologies: Discourse on the Other, translated by Brian Massumi, "Theory and History of Literature", 
is almost contractually adhered to by its participants. And what is honoured in this contractual ritual is a commutation of bodies: the captors are eating not another essentially, but themselves:

Ces muscles, dit-il, cette cher et ces veines, ce sont les vostres, pauvres fols que vous estes; vous ne recognoissez pas que la substance des membres de vos ancestres s'y tient encore: savourez les bien, vous y trouverez le goust de vostre propre chair. (I, 31, 212)

The contract is fulfilled when the avenger almost literally devours himself.

Montaigne's essay shifts, therefore, from ethnographical description that brings into play Utopian elements in a standardised idealising language- a feature it shares with Shakespeare - to the reality of the Other in all its strangeness, a strangeness that the essayist does nothing to domesticate. ${ }^{369}$ In the process, characteristics that are associated commonly in Western thought with the dispensation of justice are systematically skewed and repositioned in a conceptual framework that accords them a radically different value.

This whole process will be accelerated by the final section of the essay, where Montaigne turns from the accounts of witnesses to his own eye-witness account. At the same time, this closing section represents the climax of the momentum by which the reality of the cannibals is brought home (in more than one sense) to France. These switches in perspective are accompanied by a more overt concentration on questions of justice, and nowhere more obviously than in the second of the reactions that the cannibals give to life in France:

ils avoyent aperceu qu'il y avoit parmy nous des hommes pleins et gorgez de toutes sortes de commoditez, et que leurs moitiez estoient mendians à leurs portes, décharnez de faim et de pauvreté; et trouvoient estrange comme ces moitiez icy necessiteuses pouvoient souffrir une telle injustice, qu'ils ne prinsent les autres à la gorge, ou missent le feu à leurs maisons. (I, 31, 214)

volume 17, Manchester, Manchester University Press, 1986, p. 75. (This essay remain uncollected in French; original published as "Le lieu de l'autre. Montaigne, Des cannibales"' in Pour Léon Poliakov. Le Racisme: mythes et sciences, ed. M. Olander, Brussels, Complexe, 1981, p. 187-98.)

369 Cf. Pierre Chaunu's remarks in his preface to Lestringant's Le Cannibale: "Le Cannibale, ....c'est l'Autre vraiment autre, celui qui se place à l'extrémité de l'altérité, au pied de ce qui est fuite au-delà de l'horizon, de ce qui a cessé d'être un autre, pour se dissoudre dans le néant" (p. 18 ). 
In retrospect the superabundant fertility of the New World that Montaigne highlights earlier in "Des Cannibales" is not a neutral description of a natural state; rather, it passes judgement on the inequalities of the Old World, in the same way that the lack of division of New World goods condemns Occidental distributions, however secured in the judicial system. The premises of Western equity are thereby questioned and their inadequacies revealed, as De Certeau understands: "their speech, a critique of the injustice that divides our social body, judges us". 370

The first reaction of the natives is, if anything, more telling still:

Ils dirent qu'ils trouvoient en premier lieu fort estrange que tant de grands hommes, portans barbe, forts et armez, qui estoient autour du Roy (il est vray-semblable que ils parloient des Suisses de sa garde), se soubsmissent à obeyr à un enfant, et qu'on ne choisissoit plus tost quelqu'un d'entr'eux pour commander[.] (I, 31, 213)

It is hard to read this as anything other than a political comment on the current state of the monarchy during the Wars of Religion. It is an observation on kingly and paternal authority that has, in fact, not yet made it as far as the paternal, but has stopped short at adolescence; the boy-king Charles IX is from the Brazilian perspective an "enfant", unworthy of the honourable name of "frere" that the natives use among themselves. The point can be extended into the closing account that Montaigne gives of his exchange with the Brazilian chieftain and the leadership he displays in war, the following he has, the respect he is shown in peace time. It would have been difficult for many contemporary French readers to claim the same for their own king.

It is usual to think of this section of "Des Cannibales" as providing a relativising standpoint on the issues it contains - France seen through cannibal eyes. And that is true. But the implications of Montaigne's encounter with the cannibals, as of Shakespeare's representation of Caliban, go further and deeper. They may perhaps be regarded as exemplifications of what de Certeau termed a heterology, ${ }^{371}$ a description of cultural practices and historical

\footnotetext{
370 De Certeau, "Montaigne's 'Of Cannibals”, p. 78.

${ }^{371}$ Michel de Certeau, "Travel Narratives of the French to Brazil: Sixteenth to Eighteenth Centuries" in New World Encounters, ed. Stephen Greenblatt, Berkeley and Los Angeles, University of California Press, 1993, p. 323-28, especially p. 325 for the notion of heterology in respect of New World material; Luce Giard, "Epilogue: Michel de Certeau's Heterology and the New World", also in New World Encounters, p. 313-22.
} 
specificities proper to the Other that resist Western codifications and that create in Western texts disturbances, upheavals, anomalies. Noone remains unchanged by his encounter with the Other, says de Certeau. ${ }^{372}$ Whether Calibans or cannibals, the extent of their writing back is written into the texts of Shakespeare and Montaigne, highlighting - first - that Occidental justice is a fantasy based on class differences that accentuate disparities and inequalities; disputing secondly - the "natural" right that European princes claim over foreign soil; contesting - thirdly - the very control they purport to exercise over their own subjects since political violence lies restlessly under the surface of apparent social order.

Montaigne gives us one more vision of the cannibals in his Essais, this time in the "Apologie de Raymond Sebond":

Ce qu'on nous dict de ceux du Bresil, qu'ils ne mouroyent que de vieillesse, et qu'on attribue à la serenité et tranquillité de leur air, je l'attribue plustost à la tranquillité et serenité de leur ame, deschargée de toute passion et pensée et occupation tendue ou desplaisante, comme gents qui passoyent leur vie en une admirable simplicité et ignorance, sans lettres, sans loy, sans roy, sans relligion quelconque. (II, 12, 491)

It is a typically provocative comment, placed shortly after Montaigne's no less provocative discussion of Pyrrho's pig, who represents for him Sceptical ataraxia. ${ }^{373}$ Yet it is also a charming comment, a vignette of peace and innocence. In the event, the inhabitants of the New World were not long to enjoy such peace of mind. Nor was the King of France.

John O'BRIEN

Royal Holloway, University of London

372 Luce Giard, "Epilogue", p. 317.

373 John O'Brien, "Si avons nous une tres-douce medecine que la philosophie", in L'écriture du scepticisme chez Montaigne, ed. Marie-Luce Demonet (forthcoming). 